\title{
Adoption of improved marigold (Tagetes erecta L.) cultivation techniques among the farmers in Meerut district of western Uttar Pradesh
}

\author{
Virendra Pal*, Naveen Chandra and Omvir Singh \\ Krishi Vigyan Kendra, Hastinapur, SVPUAT, Meerut-250110 (U.P.) \\ *Email: dvpgangwar77@gmail.com
}

\begin{abstract}
Marigold (Tagetes erecta L.) is one of the most commonly grown flowers and used extensively on religious and social functions in different forms of western Uttar Pradesh. The present study was conducted in three villages in Sardhana tehsil and three villages in Mawana tehsil of district Meerut. The selection of purposively or respondents are a comprehensive list of all the marigold growers were prepared from selected villages. The production techniques of marigold flowers are largely in the hands of small and marginal farmers and productivity is low as compared to other countries. The major reasons are lack of high yielding varieties, pest and disease infestation, losses due to weed emergence, post harvest handling etc. To the findings indicated that majority of the farmers $(66.00 \%)$ had medium level of adoption regarding improved marigold cultivation techniques, while 22.33 and 11.67 per cent respondents had low and high adoption level, respectively. The study further indicated that farmers practice wise adoption of the purposively or respondents was more in time of sowing according species fallowed by irrigation, land preparation, seed rate, seed treatment and harvesting, whereas less adoption level was recorded by the farmers in practice like high yielding varieties, weed management and plant protection.
\end{abstract}

Keywords: Marigold, techniques, flowers, villages.

Paper cited: Pal, V., Chandra, N. and Singh, O. (2018). Assessment of tuberose (Polianthes tuberosa L.) cultivars used for spikes production under western Uttar Pradesh conditions. South Asian Journal of Food Technology and Environment, 4(1): 664-667.

\section{Introduction}

Marigold (Tagetes erecta L.) is one of the most popular annual flowers of western Uttar Pradesh. It is grown almost throughout the years. The marigold plants, with their attractive flower colours bloom for a considerably long period and the flower keep remarkably well when cut, Marigold flowers are sold in the market as loose or as garlands. The major marigold growing district is Meerut, Ghaziabad, Baghpat, Muzaffarnagar, Shamli and Saharanpur etc. It has gained popularity amongst gardeners and flowers and flower dealers on account of its easy culture practice and wide acceptability further its habit of profuse flowering short duration to produce marketable flower of western Uttar
Pradesh. Marigold can be grown on all type of soil from light sandy soil to heavy clay. It is very sensitive to water logging. The production of flowers in India is largely in the hands of small and marginal farmers and productivity is below the level as prevailing is other countries. The level of productivity is attributed to lack of high yielding varieties, pest and disease infestation, losses due to weed emergence, post harvest handling etc. Keeping this in view, the present study was carried out with the specific objective i.e., measures the extent of adoption of improved marigold cultivation technology by the farmers.

\section{Materials and methods}

The present study was conducted in Sardhana and Mawana tehsil of district Meerut. 
This area is famous for flowers cultivation particularly marigold. The collaborative programme was over by the year 2014-15 to be conducted in the major marigold producing area. Total six village (Lawar, Mehal \& Dauralla in Sardhana tehsil and Bhulabda, Ganeshpur \& Hastinapur in Mawana tehsil) were selected for a study. Krishi Vigyan Kendra, Hastinapur, Meerut is also working under the jurisdiction of same Sardar Vallbhbhai Patel University of Agriculture \& Technology, Meerut. For selection of purposively or respondents, a comprehensive list of all the marigold growers were prepared from selected villages. The listed farmers of each villages were categories into three categories namely ( $<1$ ha land), small (1-2 ha land) and large ( $>2$ ha land). Then proportionate sample from each category was drawn randomly to have a total sample size 60 marigold growers. Data were collected by Personal Interview Technique (PIT) through suitable structural schedule. The Farm Science centers (KVK) working in said district are supposed to disseminate the technologies / recommendations developed by university in their corresponding area through conducting various extension activities i.e, trainings, trials, demonstrations, kisan melas, kisan goshthi, exhibitions and farmers scientist interactions etc. There after data were tabulated, analysis and inferences were drawn in light of the objective.

\section{Results and Discussion}

\section{Distribution of purposively or respondents according to their overall adoption}

To get a overall view of the adoption level, the marigold farmers were grouped in to low, medium and high adoption level on the basis of calculated mean and standard deviation of the obtained adoption score points by the purposively or respondents. Data pertaining to distribution of purposively or respondents on the basis of adoption were presented in Table 1. It reveals that majority of purposively or respondents $(66.00 \%)$ fall in the medium level of adoption grouping whereas 22.33 per cent had low adoption level and only 11.67 per cent marigold growers had high level of adoption of improved marigold cultivation techniques. Further, result indicated that more number of marginal farmers and small farmers had low level of adoption as compared to large farmers.

The adoption level of large farmers was higher than small and marginal farmers. It might be due to reason that level of large farmers was comparatively higher than the marginal and small farmers. Another the season behind results may be that majority of the larger farmers were educated, resourceful and had large land holdings size. Result confirms the findings of Desai et al. (1996) in cumin crops, Poonia and Dangi (1997) in ginger crop, Meena et al., (2006) in ajwain crop and Jaitawat et al., (2008) in fennel crop. In accordance with the findings, it is recommended that all the categories of farmers specially marginal and small farmers should be motivated and encouraged to enhance the level of adoption through well planned follow up action by extension agencies or KVK,s.

\section{Practice wise adoption of advance marigold cultivation technology among the farmers}

Practice wise adoption of advance marigold cultivation technology by the marginal, small and large farmers was worked out. For this purpose mean per cent scores were calculated. The results about the same have been presented in Table 2. A close examination of data (Table 2) revealed that maximum adoption level was reported in sowing time practice with mean per cent 69.95. This was followed by the practices like irrigation, land preparation, seed rate, seed treatment and harvesting and drying with the 54.26, 50.36, 45.98, 45.06 and 43.23 per cent mean score, respectively. While, practices like manure and fertilizers, soil treatment, spacing high yielding varieties, weed management and plant protection were having less adoption level 
with mean per cent scores $38.08,32.75,22.69$, $14.39,6.16$ and 5.17 respectively. A close observation of the Table 2 shows that the adoption level was higher in case of the large farmers than marginal and small farmers in major areas of marigold cultivation technology. The large farmers had higher adoption level due to their better economic condition, higher education level so they availed desirable facilities that small and marginal farmers were deprived off. Therefore, it is suggested that marginal and small farmers should be well equipped and persuaded strategically for increasing the adoption level of improved technology of marigold cultivation. The Front Line Demonstration (FLD) may also be conducted on the field of marginal and small farmers by the KVK. The finding is similar with the revealed of Puranik and Verma (1992) in sweet potato and Jaitawat et al., (2008) in fennel crop.

Table 1: Distribution of purposively on the basis of adoption level of improved marigold cultivation

\begin{tabular}{|c|c|c|c|c|c|c|c|c|c|}
\hline \multirow[t]{3}{*}{ S.No } & \multirow[t]{3}{*}{ Level of adoption } & \multirow{2}{*}{\multicolumn{2}{|c|}{$\begin{array}{l}\text { Marginal } \\
\text { farmers }\end{array}$}} & \multirow{2}{*}{\multicolumn{2}{|c|}{$\begin{array}{l}\text { Small } \\
\text { farmers }\end{array}$}} & \multicolumn{2}{|c|}{ Large farmers } & \multicolumn{2}{|c|}{ Total } \\
\hline & & & & & & & $\%$ & & \\
\hline & & $\mathbf{F}$ & $\%$ & $\mathbf{F}$ & $\%$ & & & $\mathbf{F}$ & $\%$ \\
\hline 1. & Low $(<25.0)$ & 06 & 29.0 & 05 & 24.0 & 03 & 14.0 & 14 & 22.33 \\
\hline 2. & Medium (25.0-50.0) & 12 & 61.0 & 13 & 66.0 & 14 & 71.0 & 39 & 66.00 \\
\hline 3. & High $(>50.0)$ & 02 & 10.0 & 02 & 10.0 & 03 & 15.0 & 07 & 11.67 \\
\hline & Total & 20 & 100.0 & 20 & 100.0 & 20 & 100.0 & 60 & 100.00 \\
\hline
\end{tabular}

$\mathrm{F}=$ Frequency, $\%=$ Percentage

Table 2: Extent of adoption of improved marigold production practice by the purposively.

\begin{tabular}{|l|l|l|l|l|l|}
\hline S.No & Improved practice & $\begin{array}{l}\text { Marginal } \\
\text { farmers MPS }\end{array}$ & $\begin{array}{l}\text { Small } \\
\text { farmers }\end{array}$ & $\begin{array}{l}\text { Large } \\
\text { farmers MPS }\end{array}$ & Total MPS \\
\hline 1. & High yielding varieties & 11.85 & 14.30 & 17.03 & 14.39 \\
\hline 2. & Soil and land preparation & 45.13 & 51.24 & 54.72 & 50.36 \\
\hline 3. & Soil treatment & 33.07 & 30.01 & 35.17 & 32.75 \\
\hline 4. & Seed treatment & 27.65 & 36.12 & 71.42 & 45.06 \\
\hline 5. & Seed rate & 51.35 & 38.83 & 47.77 & 45.98 \\
\hline 6. & Time of sowing fertilizer & 32.06 & 71.45 & 72.55 & 69.95 \\
\hline 7. & Recommended spacing & 21.45 & 19.85 & 26.78 & 22.69 \\
\hline 8. & $\begin{array}{l}\text { Manure \& } \quad 38.92 \\
\text { application }\end{array}$ & 45.08 & 53.01 & 64.28 & 38.08 \\
\hline 9. & Irrigation & 4.71 & 5.81 & 7.97 & \\
\hline 10. & Weed management & 7.66 & 3.78 & 6.16 \\
\hline 11. & Plant protection measures & 4.08 & 39.85 & 46.44 & 5.17 \\
\hline 12. & Harvesting and drying & 43.41 & & 43.23 \\
\hline
\end{tabular}

\section{Conclusion}

The findings indicated that majority of the farmers (66.00 per cent) had medium level of adoption regarding improved marigold cultivation techniques, while 22.33 and 11.67 per cent purposively or respondents had low and high adoption level, respectively. The study further indicated that practice wise adoption of the respondents was more in time of sowing 
followed by irrigation, land preparation, seed rate, seed treatment and harvesting and drying, whereas less adoption level was recorded by the farmers in practice like high yielding varieties, weed management and plant protection.

\section{References}

1. Desai, C.P., Pandey, D.N., Patel, M.R. and Patel, A.A. (1996). Farmer's satisfaction with adoption of cumin cultivation. Gujarat Agricultural University Research Journal, 21 (2): 72-75.

2. Jaitawat, G.S., Bhimawat, B.S. and Sisodia, S.S. (2008). Adoption of improved fennel cultivation technology by the farmers in Sirohi district. Rajasthan
Journal of Extension Education, 16: 158161.

3. Meena, R., Sharma, C., Sharma, V.P., Bhimawat, B.S. and Dadheech, B.S. (2006). Adoption of improved ajwain production practices among the farmers of Dungla tehsil in Chittorgarh district. Rajasthan Journal of Extension Education, 14: 47-51.

4. Poonia, P.P. and Dangi, K.L. (1997). Adoption behavior of ginger growers. Maharashtra Journal of Extension Education, 16: 116-119.

5. Puranik, R.P. and Verma, P.R. (1992). Adoption of sweet potato technology. Indian Journal of Extension Education, 28: 114-116.

$\begin{array}{ll}\text { Received } & \text { : Feb., } 2018 \\ \text { Revised } & \text { : May, 2018 } \\ \text { Published } & \text { : June, 2018 }\end{array}$

